\title{
LAUGHING TO LEARN: IRONY IN THE REPUBLIC AS PEDAGOGY
}

\author{
Jonathan Fine ${ }^{l}$
}

\begin{abstract}
Although recent commentators have attended to dramatic and ironic aspects of Plato's Republic, a more sustained examination of the relation between irony and the exchanges of Socrates and Glaucon is required because a crucial purpose and presentation of the irony have largely gone unnoticed. This paper argues that Socrates employs irony in part to parody Glaucon's extremism and that he does so to exhort Glaucon to think critically. First, it examines how Socrates uses the term makaria (blessedness) primarily ironically and pedagogically. Then, a possible reason for this use of makaria is advanced: aspects of Kallipolis are a parody of Glaucon and that the parody aims to instruct Glaucon intellectually. This paper hopes to show that such a reading deserves further articulation and examination.
\end{abstract}

There is a lengthy tradition of interpreting the Republic, probably dating back to Aristotle, which holds that the dialogue contains Plato's positive prescription for an ideal political regime. ${ }^{2}$ This tradition relies on the fact that Plato has his protagonist, Socrates ${ }^{3}$ and his interlocutors say that they are embarking on precisely that project. In contrast to this tradition, recent commentators have emphasized the work's dialogical structure and have drawn on dramatic, narrative and stylistic features in an effort to argue that such utopianism is ironic. ${ }^{4}$ I want to propose a reading of the Republic of the second kind. However, I believe that a complete account of the purpose of the irony requires a more sustained examination of the relation between irony and the exchanges of Socrates and Glaucon than I have found in the literature. As a result, a crucial purpose and presentation of the irony have largely gone unnoticed. I argue that Socrates employs irony in part to parody Glaucon's extremism and that he does so to exhort Glaucon to think critically. First, I examine how Socrates' use of the term makaria (blessedness) is primarily ironic and pedagogic

${ }^{1}$ Department of Philosophy, Columbia University, 708 Philosophy Hall, 1150 Amsterdam Avenue, NY 10027, USA. Email: jdf2157@ columbia.edu

${ }^{2}$ See Aristotle, Politics II.1-5.

3 'Socrates' will refer only to the character in Plato's dialogues and not to the historical Socrates.

${ }^{4}$ See for example: G.R.F. Ferrari, 'Glaucon's Reward, Philosophy's Debt: The Myth of Er', in Plato's Myths, ed. Catalin Partenie (Cambridge, 2009), pp. 116-33; Arlene Saxonhouse, 'The Socratic Narrative: A Democratic Reading of Plato's Dialogues', Political Theory, 37 (2009), pp. 728-53; Ruby Blondell, The Play of Character in Plato's Dialogues (Cambridge, 2004), esp. chs 1 and 4; Charles L. Griswold, 'Irony in the Platonic Dialogues', Philosophy and Literature, 26.1 (2002), pp. 84-106; Gene Fendt and David Rozema, Platonic Errors: Plato, a Kind of Poet (Westport, CT, 1998); and Arlene Saxonhouse, 'Comedy in Callipolis: Animal Imagery in the Republic', American Political Science Review, 72.3 (1978), pp. 888-901.

POLIS. Vol. 28. No. 2, 2011 
as a corrective to intellectual complacency. Then, I suggest three reasons to think that the way in which Socrates uses makaria makes possible an ironic reading on which Socrates' construction of Kallipolis is a parody of Glaucon that aims to instruct Glaucon intellectually. If it is correct, then my ironic reading weakens totalitarian interpretations of the Republic and goes beyond those that attribute ironic endorsement of Kallipolis only to Plato. I hope to show that such a reading deserves further articulation and examination.

\section{Blessed Irony}

In order to examine the use of irony in the Republic in relation to Socrates and Glaucon, I must first make a terminological distinction and second discuss two forms of irony that will figure prominently for us. First, attention to dramatic features of Plato's works requires a distinction between narrative levels, or what Iakovos Vasiliou calls the 'inner' and 'outer' frames. The inner frame is a relation between interlocutors whereas the outer frame is a relation between the reader and the text. ${ }^{5}$ These frames can be multilayered. The Republic, for example, is Plato's dialogue in which a character named Socrates narrates to four silent interlocutors ${ }^{6}$ the previous night's conversation, which he enacts. For the sake of simplicity, given the structure of the Republic, call the conversation with Glaucon, Adeimantus and so forth that Socrates reports the inner frame. The narration will constitute the outer frame. Of course, because Plato never speaks to us directly, it is Socrates who technically speaks in both frames. Let us say, then, that irony is Socrates' when it is applied by Socrates in the inner frame and that it is Plato's irony when it is applied by Plato, via Socrates, in the outer frame. Note that, in this sense, all irony in Plato's dialogues belongs to Plato because the inner frame presupposes the outer frame; Socrates' words are, after all, written by Plato for the reader to venture into the narrative of Socrates and company. The overarching relation inherent to dialogical frames allows Plato to communicate a philosophical point for his readership through the drama of the inner frame, that is, through the way in which Socrates interacts with his interlocutors. Again, the irony in the Republic is always meant for us, although it may sometimes be concomitantly meant for an interlocutor.

With this in mind, let us first consider irony in general. My aim here is to draw on the work of Gregory Vlastos and Vasiliou in order to prepare us for Socrates' ironic use of makaria. Irony minimally requires that words are used to express a meaning that is contrary to, and sometimes the opposite of, their literal meaning. Normally (if I'm not overly cheerful), if it is hailing outside,

5 Iakovos Vasiliou, 'Conditional Irony in the Socratic Dialogues', Classical Quarterly, 49 (1999), p. 464.

${ }^{6}$ Cf. Timaeus $17 \mathrm{a}$. 
then my statement 'It sure is beautiful today' is ironic because what the words literally say is not what I mean: that the weather is not beautiful and, in fact, that it is ugly and depressing. I do not intend to deceive my audience with this comment. On the contrary, I want to communicate clearly the fact that I dislike the weather. To speak ironically is to speak genuinely. ${ }^{7}$ Vlastos offers a second example of irony in which a tutor, exasperated by a student's poor performance, exclaims, 'Paul, you are positively brilliant today'. If Paul has a conceit of knowledge, he may misconstrue his tutor's exclamation as a compliment. This reception would contravene the intention of the tutor, for he does not want Paul to think that he has performed brilliantly. ${ }^{8}$ So although the tutor's irony precludes an intention to deceive, the tutor does intend to mock Paul. Perhaps upon recognition of his tutor's mockery, Paul's shame will move him to attend more to his scholastic efforts. We will see many examples of this species of general irony in exchanges between Socrates and Glaucon, which will illuminate the pedagogical side of irony in general and the ironic use of makaria in particular.

A second form of irony prominent in Plato's works is what Vasiliou calls 'conditional irony'. In conditional irony, Socrates' interlocutor believes the antecedent of some conditional statement, while the reader is or may be aware that Socrates does not believe the antecedent. However, Socrates believes that the whole conditional statement is true: if the antecedent were true, then Socrates would believe the consequent. Socrates does not believe the antecedent and he does not believe the consequent. To borrow a clear example from Vasiliou, consider when Socrates asserts that if Euthyphro has sufficient knowledge of piety to prove the correctness of prosecuting his father, then 'I shall never stop praising your wisdom' (Euthyphro 9b). Any reader who is familiar with Socrates' modus operandi, or even one who follows the plot of the Euthyphro, knows that Socrates does not believe that Euthyphro has knowledge of piety. Still, Socrates believes that if Euthyphro had such knowledge, then he would praise him endlessly. ${ }^{9}$ I assume that, although it is not a sure measure, the explicit reiteration of an antecedent is a clue that Socrates might be employing conditional irony. Reiteration brings attention to the antecedent, at the very least in order to remind the audience that what follows is logically dependent upon it and, perhaps, to call the antecedent into question. We cannot look to the inner frame for guidance here, because conditional irony is usually graspable only by the audience of the outer frame. The reason for this is that Socrates employs conditional irony in order to exploit

${ }^{7}$ It is well-established that the Attic Greek conception of eirōneia is distinct from our conception of irony. Eirōneia necessarily requires that the speaker intend to deceive and to shame her hearer. I will not be concerned, as are Vlastos and Vasiliou, with assessing whether Socratic irony replicates or moves beyond the concept of eirōneia.

${ }^{8}$ Gregory Vlastos, 'Socratic Irony', Classical Quarterly, 37 (1987), pp. 79-80.

${ }^{9}$ Vasiliou, ‘Conditional Irony’, p. 462. 
his interlocutor's conceit of knowledge and thereby disabuse him of that conceit. If his interlocutor grasped the conditional irony, then Socrates would not need to use it. Importantly, Socrates cannot simply tell his interlocutor that the antecedent is false, for this would violate his goal to develop their capacities for independent criticism and reflection. More generally, conditional irony is 'a companion to the elenchus, which aims at getting the interlocutor to appreciate the difficulty the elenchus has caused, and thus to incite aporia' in both a thoughtful interlocutor and a careful reader. ${ }^{10}$

Moving now to the text itself, I want to focus on a pattern in the Republic of ironic uses of the term makaria ( $\mu \alpha \kappa \alpha$ ó $\alpha$ ), meaning 'blessedness', 'bliss' or

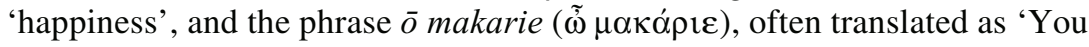
blessed man'. I will show that this phrase is not only ironic but also often pedagogic, as a signal to provoke critical thinking and to recognize irony. As the English 'blessedness' conveys, makaria includes the notion of receiving a good fortune from divinities, and because of this, it is typically used in reference to mortal humans. However, the term may be applied to the lesser gods, albeit in the singular. Most important for our purposes, however, is that makaria has an ironic usage that means 'foolishness' or 'nonsense'. ${ }^{11}$ The ironic meaning of makaria is well known; however, to my knowledge no one has either examined the use of makaria in any of Plato's dialogues or even mentioned its ironic usage in commentaries. ${ }^{12}$ A derivate of makaria first appears in the Republic at 335e when Socrates calls Simonides, Bias, and Pittacus 'wise and blessed' (sophon te kai makarion) for saying that the just person does harm, immediately after Socrates and Polemarchus have argued otherwise. ${ }^{13}$ By using makarion in this context, Socrates calls these poets foolish for spouting nonsense. It might be thought that Socrates is not ironic here, that he thinks that these poets, although incorrect, are still wise. However, Socrates goes on to denigrate whoever asserted that justice requires harming enemies as some 'rich man who has a high opinion of what he can do' (336a). This confirms that 'blessed' at 335e is ironic. To be sure, not all instances of makaria in the Republic are ironic. Thrasymachus cites the popular opinion that an unjust man is 'happy and blessed' (eudaimones kai makarioi) (344b-c), while Socrates sets out to show that justice affords a life

10 Ibid., p. 472.

${ }^{11}$ Henry George Liddell and Robert Scott, An Intermediate English-Greek Lexicon (Oxford, 8th edn., 1889), p. 484. The ironic usage of makaria is connoted by Thucydides: 'blessing your happy ignorance' (makarisantes umon to apeirokakon) (5.105).

12 The closest intimation I have found is by Seth Benardete, who translates makarie as 'blessed innocent' in those places where 'there seems to be in Plato a suggestion of naivete'. See The Being of the Beautiful: Plato's Theaetetus, Sophist, and Statesman, trans. Seth Benardete (Chicago, 1984), p. 172, n.42.

${ }^{13}$ Unless specified otherwise, all parenthetical citations refer to Plato, Republic, trans. Allan Bloom in The Republic of Plato (New York, 2nd edn., 1991), pp. 3-303. Direct quotations are from Bloom. 
that is makarios (354a). Yet the insult of the poets at 335e seems to set up the use of makaria as predominantly ironic and derogatory throughout the work. Socrates calls Thrasymachus, his principal target, blessed (makarie) (345b, 354a) and describes the tyrant as blessed three times because he is necessarily either hated by everyone or forced to murder them (567c-568a; cf. 574c). Surely Socrates cannot mean that the tyrant is well-fortuned, and especially not in virtue of the disagreeable reasons that he cites. Taking Socrates seriously cannot make sense of these passages.

Specifically, Socrates' use of 'You blessed man' (o makarie) is exclusively ironic, most often with reference to the intellectual ineptitude of his interlocutor. At Euthyphro 12a, Socrates tells Euthyphro, 'Come, you blessed man [ō makarie], exert yourself, for it isn't even hard to understand what I am saying'. He says elsewhere: 'blessed man, stop telling me the same argument ...' (Crito 48e). The phrase appears also at Gorgias 512d, where Socrates exhorts Callicles to consider the difference between preservation of mere life and man's goal to achieve the best life. In all these cases, which are markedly similar to Vlastos' example of the ironic tutor, we cannot account for the presence of makarie if we read it straight. Indeed an ironic reading of $\bar{o}$ makarie as 'you fool' conforms to the dramatic context and to Socrates' explicit disdain for the intellectual performance of his interlocutors. We see this same presentation of Socratic irony in the Republic. Consider first when Thrasymachus argues that the unjust man profits more greatly than the just man. Socrates remains unconvinced and challenges him: 'So persuade us adequately, you blessed man [ō makarie], that we don't deliberate correctly in having a higher regard for justice than injustice' $(345 \mathrm{~b})$. Socrates cannot think that Thrasymachus is blessed either for trying to champion injustice or for inadequately doing so. Or when Adeimantus says that the many cannot recognize the philosophic person and think that it is impossible for him to rule (499c-d), Socrates responds: 'You blessed man ... don't make such a severe accusation against the many ... I believe so hard a nature is in a few but not the multitude' (499b-500a; cf. 506d). Again, Socrates cannot mean that Adeimantus is truly blessed by mistaking the capacities of the many. Rather, Socrates means that Adeimantus is one of the few who cannot recognize the philosopher and his value. Similarly, Socrates uses the phrase 'you blessed man' in his suggestion of how to persuade the man who blames justice, in virtue of not knowing what is truly just (589c). The blamer of justice is not actually blessed - so makarie should be read in its ironic meaning — and o makarie here, as before, is tied to the intellectual pedagogy inherent in educating someone about what things are just. Thus, not only is $\bar{o}$ makarie consistently ironic, but it tends to occur in a narrow set of circumstances in which Socrates' interlocutor is deficient in criticism and Socrates exhorts him to think more critically.

The restricted context in which $\bar{o}$ makarie usually appears casts doubt on the possibility that $\bar{o}$ makarie functions as a vacuous conversational locution. 
However, precisely because of this context, in conjunction with the ironic meaning of makaria as 'foolishness', we might think that the formulation amounts to only an insult. After all, its first appearance in the Republic at $341 \mathrm{~b}$ is just that. There, Thrasymachus has just called Socrates a 'sycophant' (341a) and warns Socrates that he cannot out-argue him. Socrates replies: 'Nor would I even try, you blessed man [ō makarie]'. This retort is clearly ironic and hostile, and there is no suggestion that Socrates is attempting to instruct Thrasymachus. So might the other instances of $\bar{o}$ makarie be just insults? I do not think so. I recognize that shame is central to this particular case of Socratic irony, and perhaps this aspect characterizes $\bar{o}$ makarie as an insult; but it cannot always be just an insult. If it is exclusively an insult, we must ask whether it is supposed to be veiled or not, that is, whether the interlocutor is meant to realize that he has been called foolish through the use of irony. Socrates is insulting his interlocutor to his face - and the contextually inappropriate use of makaria hardly constitutes the veil necessary for deceit. So the interlocutor could be wise to the insult. Usually, that serves Socrates' purpose directly. Although he often mocks, Socrates is always a pedagogue: ${ }^{14}$ we have seen the formulation $\bar{o}$ makarie often appear alongside an explicit exhortation to think critically. In these cases, it seems reasonable that, rather than merely insulting his interlocutor, Socrates wants his interlocutors to understand their foolishness or, as in conditional irony, to untangle the perplexity involved in being praised when the circumstances warrant otherwise. Because of this, we may see that the phrase is usually ironic for a purpose, namely, to remedy the deficiency in critical examination. Two particular examples in which the phrase is directed at Glaucon make this evident. These cases will suggest a purpose of the irony, and the form it takes, in the wider context of the dialogue.

In the first instance, Glaucon and Socrates are searching for justice in Kallipolis. Socrates exclaims:

Here! Here! [iou iou $]$... It appears, you blessed man [ō makarie], that it's been rolling around at our feet from the beginning and we couldn't see it after all, but were quite ridiculous. As men holding something in their hand sometimes seek what they're holding, we too didn't look at it but turned our gaze ... (432d-e)

It seems Socrates thinks that he too has been a 'stupid' and 'ridiculous' person who cannot even see what is in his hands or at his feet (432d). This reading gains strength from the fact that Plato has Socrates narrate to the reader in the outer frame, 'I caught sight of it and said ...' (432d), as though Socrates really did locate justice. However, if we say that Socrates thinks he too has been inept, then we cannot explain the presence of $\bar{o}$ makarie. We cannot explain its presence because Socrates could not then justifiably call Glaucon

${ }^{14}$ Cf. Griswold, 'Irony in the Platonic Dialogues', p. 93. 
a fool. And if the phrase is not ironic here, then we cannot explain why Socrates thinks that Glaucon is blessed. A non-ironic, non-pedagogic reading of $\bar{o}$ makarie also misses what immediately precedes this passage (432c). Having already directed Glaucon 'to join in' their dialogue (427e), Socrates again encourages Glaucon to take part in the argument himself: 'Look to it and make every effort to catch sight of it; you might somehow see it before me and could tell me.' Even amidst motivation, Glaucon refuses to engage independently and critically, and he explicitly asks to be used as a 'follower' (cf. 'just lead'). At least during this exchange, Glaucon operates at the level of trust and wants simply to receive opinions, not to actively pursue knowledge. Hence, we might think that Socrates is frustrated. Indeed, he might be - Allan Bloom notes that iou, iou is an expression of both grief and joy. ${ }^{15}$ It is possible that Socrates trades on this double meaning; he laments over Glaucon's intellectual complacency, though he knows that Glaucon will interpret iou, iou as joyous. At any rate, Plato is aware of the double meaning and exploits it humorously for the reader in the outer frame. On my view, Socrates knows where justice is and creates an intellectual exercise for Glaucon. My reading is consistent with and bolstered by the pattern of ironic uses of makaria and Socrates' use of $\bar{o}$ makarie when his interlocutors fall short intellectually.

A second exchange between Socrates and Glaucon deserves close attention. After Glaucon too eagerly assents to Socrates' proposals (cf. 434b-c, 500d) and wants to follow in the argument, as we just saw, Socrates tries to get him to take a greater part in their discussion by asking him who will receive their education programme. However, Glaucon altogether refuses to contribute substantively, as he does not even attempt an answer: 'That's plainly the next question' (535a). On the back of Glaucon's uncritical receptivity and passivity, Socrates states the qualities of the rulers who will receive their education: 'Keenness at studies, you blessed man [ō makarie $]. .$. is a prerequisite for them ...' (535b). O makarie must be ironic here, and the immediately preceding exchanges between Socrates and Glaucon allow us to see that Socrates attempts to motivate Glaucon to be keen at studies, to ask questions and to criticize. This goes towards a pattern that establishes a pedagogical aspect of $\bar{o}$ makarie as an ironic exhortation to engage in critical thinking.

\section{II}

\section{Glaucon, Parody and Pedagogy}

The above passages show that Socrates employs general irony under a specific presentation (makaria and $\bar{o}$ makarie) in order to exhort Glaucon to engage more critically in their discussion, when Glaucon proximately exhibits a lack of intellectual effort. Think back to Paul's tutor admonishing him when Paul flounders in his studies. Socrates similarly, and repeatedly, calls Glaucon a

15 Bloom, The Republic, p. 456 n.19. 
fool to his face. Of course, Glaucon does not notice. In the same way that conditional irony works, Socrates thus parodies Glaucon's lack of intellectual rigour, a deficiency evident in his failure to recognize the ironic meaning of makaria. In fact, Plato surrounds the character of Glaucon in irony. One of the first things Plato tells us about Glaucon is that he 'is always most courageous in everything' (aei andreiotatos) (357a). We learn of two types of courage throughout the Republic, political and philosophic. The former consists in one's ability to steadfastly retain and enforce opinions (430b). The latter consists in the ability to criticize opinions and to speak frankly (567b). Although Glaucon does courageously reinvigorate Thrasymachus' argument and ask Socrates to persuade him of the superiority of justice to injustice, we discover that, in his intellectual complacency, Glaucon is hardly the exemplar of philosophic courage. He also lacks some political courage with an occasional failure to retain opinions $(474 \mathrm{c}-\mathrm{d}, 520 \mathrm{a}, 535 \mathrm{a}, 612 \mathrm{c})$. The above passage at $535 \mathrm{a}-\mathrm{b}$ is an apt illustration. When asked what the qualities of the guardians, who would receive their education, were, Glaucon replies, 'How could I not remember?' but he does not elaborate (cf. 612c). Firstly, Glaucon's response is unlikely to be the answer of someone who does remember. Secondly, the above exchange is strikingly similar to an exchange between Socrates and Adeimantus at 504a, in which Adeimantus' memory does clearly fail him:

Adeimantus: If I didn't remember, it would be unjust for me not to hear the rest.

Socrates: And also what was said before that?

Adeimantus: What was it?

The pretention of Adeimantus' first line suggests that he certainly remembers, a certainty immediately belied by his inability to remember what came before. This is a humorous exchange and Plato means us to laugh at Adeimantus. Returning to the case with Glaucon, Socrates goes on to proclaim that the 'most courageous' (tous andreiotatous) men will be selected as rulers and that these men will also be keen at studies, and he calls Glaucon a blessed man (535a-b). The dramatic context reveals a deficiency on Glaucon's part in both philosophic and political courage, thus placing him far from the status of 'most courageous in everything'. Plato's remark about Glaucon at 357a is an ironic jab that should prepare the reader for a parody of Glaucon. On my view, the jab gets recalled at 535a-b in the inner frame and supplemented with specific uses of $\bar{o}$ makarie. But what has Glaucon done, or not done, to incur such mockery? It cannot be just that he does not know the nature of justice or how to prescribe an education system for the guardians. Not only are these sophisticated issues, but these instances are symptomatic of, and their dramatic contexts illustrate, a more general lack of criticism. Still, a few lapses in effort and not being as philosophic as Socrates do not deserve ironic barbs. So, we must 
ask: just how deep does Glaucon's intellectual attitude run and how diffuse are its effects in the Republic?

To anticipate my answer to this, I will argue that Glaucon is what I will call an extremist and that Socrates exploits this quality through the use of irony, which intends to remedy it. I will emphasize one possible ramification of this interpretation, which is that aspects of Kallipolis are a parody of Glaucon and that a central purpose of the parody and irony is to instruct Glaucon intellectually. So, let us take a closer look at Glaucon. Two features about Glaucon are important for our purposes. Characteristic of his masculine honour, he firstly has a conceit of knowledge. This makes him too eager to assent to proposals and too uncritical of his own opinions and their implications. After Socrates suggests that justice consists in minding one's own business, Glaucon agrees wholeheartedly and Socrates must rein in his quick consent: 'Let's not assert it so positively just yet' (434c; cf. 500d). Likewise, Socrates must remind him that 'it's not too fit to be sure' that the guardians have been well educated in Books II and III (416b). Readers will similarly recall the myriad of exchanges in which Glaucon receives Socrates' every proposition with enthusiastic affirmations such as 'Quite right' and 'Of course'. The second important feature is that Glaucon is an extremist, which I mark by two necessary conditions. The first is that Glaucon's desires are immoderate, tending to the poles instead of a middle-ground. For instance, he believes that Socrates must defend an 'extreme' of justice (361d) in which the just man will be tortured and killed (361e-362a). We see Glaucon's immoderation again when he objects to the simple city of necessity on the grounds that it lacks gastronomic delights (372c) and when he maintains that if one does not have a couch, one lives poorly: 'I suppose that men who aren't going to be wretched recline on couches ...' (372d). This facet of what I have called extremism corresponds to Allan Bloom's analysis that Glaucon is an 'idealist'. I agree with Bloom that Glaucon admires traits to the full degree that they admit, such as perfect self-indulgence and perfect abstinence, and that he can admire exemplars of both poles. ${ }^{16}$ In my view, this reveals a second feature that is not obviously drawn out from Bloom's sense of idealism. As I intend it, extremism carries with it a doxastic mechanism; equally pertinent is that Glaucon moves from one extreme belief to the other when that belief is minimally impaired. $\mathrm{He}$ first conceives of justice as an intrinsic good and a state of the soul that is irrespective of all bodily conditions and sufficient for the best life (361d-2a). Therefore, on the one hand, Glaucon entirely ignores the fact that humans are partly constituted by a body. He forgets about the body, as it were. On the other hand, his desire for relishes and couches demonstrates his immoderate desire for kalon things, that is, beautiful and noble things. While kalon desires are not strictly epithumetic goods of the body, they are closely tied to thumos (spiritedness) and we see Glaucon's thumos bring the body into an important

${ }^{16}$ Allan Bloom, 'Interpretive Essay', in The Republic of Plato, p. 347. 
role that opposes his earlier neglect of the body. The body is central to Glaucon's governing principle, for it is partly with the body that he must discriminate the luxurious goods that enter into Kallipolis. Bloom's term conveys the move to extremes but I think that 'extremism' better carries the doxastic strategy to move among extremes.

Glaucon's move to and among extremes relates to his eagerness and conceit of knowledge. Glaucon is Plato's paradigm of thumos (even though he isn't 'always most courageous in everything'), and so he often eagerly assents to propositions and, in this process and thereafter, does not submit them to sceptical questioning. Like the guardians of Kallipolis, he then holds onto them as his own, with spiritedness and resolve. Because of this, if that belief is made suspect, then its opposite is adopted to fill in the lacuna left by the first. Glaucon cannot afford ambivalent beliefs and self-doubt; it's tricky to immoderately value moderation or to impatiently endorse patient criticism and reflection! However, Glaucon's intellectual attitude is easy. It favours following beliefs and following a rule in order to arrive at which beliefs to adopt, rather than independently engaging with complexities, subtleties and delineations. His extremism manifests the same lack of effort exhibited in his 'following' Socrates and ignoring, or at least not being open to, Socrates' exhortations to play a larger and more critical role in their discussion. Of course, we know that Socrates does not think that Glaucon's strategy is good and that he champions dialectic instead in virtue of its active negotiation of extremes (454a-b). Unlike eristic, dialectic considers an object in its specificity. Eristic rests on contradiction, and thus it cannot 'consider what's said by separating it out into forms [kat' eide diairoumenoi]' (454a). Contradiction simply asserts the reverse of what was said, no matter what was said, and as such it does not look inside to examine the actual semantic content of propositions. ${ }^{17}$ Glaucon similarly fails to appreciate a view in its specificity when he immediately and eagerly assents to it, believing it to be certain and accepting it to the limit of how far it can go. Dialectic, though, does not rest on this mistake. In the formal sense of 'dialectic' as a technical art of language and argument (dialektikē), dialectic consists of the collection of particulars under one idea and the subsequent diairesis, a process of differentiation and classification, of those ideas into forms. ${ }^{18}$ In the non-technical sense of 'dialectic' akin to conversation (dialegesthai), dialectic includes the processes of exchange, revision and refinement of the Socratic elenchus. ${ }^{19}$ On either score, the Socratic model of education rejects extremism in favour of a more careful and

17 Cf. Soph. 276d. The famous Argument Clinic sketch from 'Monty Python's Flying Circus' (originally aired 2 Nov 1972) is a hilarious example of this.

${ }^{18}$ Bloom, The Republic, p. 453 n.50.

19 David Roochnik, Beautiful City: The Dialectical Character of Plato's Republic (Ithaca, 2003), pp. 133-40. 
active process. ${ }^{20}$ Since Socrates employs irony as a pedagogical tool to inculcate this philosophic ethos, then Glaucon is a ripe target for an ironic lesson.

I want now to suggest three very preliminary reasons to think that this lesson is just what Glaucon gets and that it comes most visibly in the articulation of the laws of Kallipolis in Book V. The idea would be that Socrates ironically endorses aspects of Kallipolis that he intends as a parody of Glaucon's extremism, so that Glaucon will think more critically. I should say that I cannot convincingly demonstrate this claim. For I can neither fully determine which aspects are parodic (I will suggest some that seem so) nor can I explain away some issues that this interpretation raises (I will mention some near the end). I only want to motivate this ironic reading, to put it on the table so that we may articulate and consider it further.

Historically, the reforms advanced in Republic V especially have motivated some commentators to consider the Republic to be Plato's blueprint for or idealization of a totalitarian regime, most famously Karl Popper. ${ }^{21}$ Totalitarian assumptions assume both that Socrates seriously endorses Kallipolis and that Plato believes what Socrates seriously says. If we are open to the presence of irony, then we make space for an interpretation on which Plato uses Socrates to construct a parody of Glaucon that attempts to disabuse him of his extremism and to teach him to think critically. Now, the claim that Kallipolis is in some sense ironic is not novel. However, many who argue that Plato is ironic either do not believe that Socrates also ironically endorses the regime in the inner frame or are silent on the matter. ${ }^{22}$ I think that Socrates' pedagogic use of conditional irony and makaria in relation to Glaucon's extremism might signal that Socrates, and not just Plato, is less serious about the city than is traditionally thought. The first reason to think that this is so is that it is Glaucon's extremism that motivates Kallipolis. His desire for luxurious goods introduces war (372e) and, in turn, guardians (374a). Then he switches to the other extreme by forgetting about the body and its natural attachments; hence family and sexual appetite are either eliminated from Kallipolis or restrained for the sake of the city. Glaucon even voices his transition among extremes but shows that he is unaware of it. After the luxuries are 'purged' and the luxurious city becomes an ascetic one, he naïvely exclaims,

${ }^{20}$ Cf. Rep. 518 c for Socrates' image of education as 'turning' of the soul.

${ }^{21}$ See Karl Popper, The Open Society and Its Enemies, Vol I: The Spell of Plato (Princeton, 5th edn., 1971). C.C.W. Taylor has more recently argued that Plato champions a paternalistic species of totalitarianism in 'Plato's Totalitarianism', in Plato's Republic: Critical Essays, ed. Richard Kraut (Lanham, MA, 1997), pp. 31-48; originally published in Polis, 5 (1986), pp. 4-29.

22 Stanley Rosen, for example, writes that 'Socrates is quite serious about his account of the best city' and that he 'never wavers from the endorsement he bestows upon it'. See S. Rosen, Plato's Republic: A Study (New Haven, 2005), p. 390. See also Bloom, 'Interpretive Essay', pp. 380-1, p. 387; and Saxonhouse, 'Comedy in Callipolis', pp. 889-91, p. 896. 
'That's a sign of our moderation' (399e). It seems far from moderate I think Plato is joking at Glaucon's expense for the reader — and its implications, such as the law that guardians be sleep-deprived to be more efficient (404b), seem not only less than ideal but laughable. Founded on his extremism and unwillingness to examine Socrates' suggestions, Glaucon is reminded several times that Kallipolis is ideologically his city: 'your city would now be founded' (427d); 'you, their lawgiver' (458a); the city is made 'to gratify you' (472e).

Second, there is evidence that Socrates does not believe that he and Glaucon have created a good city. He says that he is afraid to interpret arguments on Glaucon's behalf (453c-d). He tells Glaucon that in specifying the laws of Kallipolis, he is 'slipping from the truth' and will prostrate himself before Adrasteia (451a), who punishes the arrogant and the immoderate. ${ }^{23}$ Put otherwise, Socrates thinks that Glaucon's city requires arrogant and immoderate proposals. What's more is that Socrates does not want to do this: he likens his project to an unwilling murder (450d-451b). So Socrates seems to suggest several times and in several ways that the constitution of Kallipolis must be questioned critically. First, his praise of it seems marked by conditional irony at its finest. He claims, 'Good ... and right is what I call such a city ... if this one is really right' (449a) and that the city is well-founded 'if founded right' (427e). If these statements are not conditionally ironic, then they amount to tautologies. After Glaucon misses these opportunities to re-evaluate their proposals, Socrates increases the force of his scepticism and pedagogical push, stating explicitly that 'it admits of many doubts ... that the things said are possible; and, even if ... they could come into being, that they would be what is best' $(450 \mathrm{c}-\mathrm{d})$. That Socrates intends to provoke criticism here is further mitigated by his application of the phrase 'you happy man'

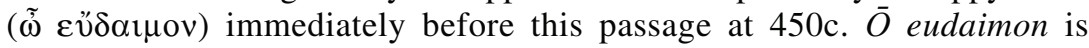
probably ironic here; the contextual, syntactic and semantic similarities with $\bar{o}$ makarie probably imply that it serves the same ironic and hortatory function. Socrates twice reiterates these doubts about the possibility and, more importantly, the goodness of their imagined regime (457d, 471c).

The third reason is that Socrates seems to present absurdities that are supposed to follow from Glaucon's strongly-held and extremist commitments. Many laws of Kallipolis rest on the assumption that the life of a human being is isomorphic to that of a $\operatorname{dog}(459 \mathrm{a}-\mathrm{b}, 466 \mathrm{~d}, 467 \mathrm{a}-\mathrm{b})$. Glaucon agrees to the identification of humans and dogs at 375a, and when it returns in Book V, Socrates twice employs conditional irony to make him retract it: the guardians must procreate as dogs do 'if it is also the same with the human species' (459b) and 'if the flock is to be of the most eminent quality' (459e). These are plausibly cases of conditional irony because it is difficult to imagine how Socrates could believe that human sexual, social and political practices are

${ }^{23}$ Bloom, The Republic, p. 458 n.6. 
identical to those of dogs; and if they are not identical to dogs, then Socrates does not believe the second antecedent either, for the guardians will not be most eminent if treated like dogs. Yet Glaucon is certain even in the face of Socrates' suggestions to the contrary (460c). Far from an isolated incident, Arlene Saxonhouse has shown that comical animal imagery and vocabulary pervades descriptions of the guardians in Book V. ${ }^{24}$ The sub-human treatment of supposedly ideal figures is a consequence of Glaucon's intellectual passivity. In a similar vein, Socrates contradicts earlier proposals about the guardians with new ones in keeping with Glaucon's desires. ${ }^{25}$ For instance, whereas before the guardians did not need honour (416e) and avoided sexual appetites $(403 \mathrm{a}-\mathrm{c})$, they must now be given many honours, one of which is that no one may refuse to kiss them $(468 \mathrm{a}-\mathrm{c})$. Before, children were carefully educated in music and gymnastics (376e-402a), but now they are taken to watch wars $(466 \mathrm{e}-467 \mathrm{~d})$. Socrates even seems to use a derivative of makaria to signal the foolishness of guardian life: they 'live a more blessed life [makaristou biou] than even the Olympic victors' (465d). Earlier, we saw a pattern of ironic and pedagogic uses of the term makaria. Apart from this use of makaria and conditional irony, Socrates suggests a parodic intent several times by stating that he was 'paradoxical' (472a) and 'playing' (536c), and later calling the social programme of Book V a 'detour' (543c). We must remember that these 'blessed' reforms are, at the very least partially, the by-product of Glaucon's extremist and uncritical nature. Given this, if Socrates suggests and endorses those reforms to exhort Glaucon, then aspects of Kallipolis are a parody of Glaucon because he refuses to think critically and so that perhaps he may think critically. This view would fit well with Socrates' ironic use of makaria towards Glaucon, but like I said, it remains to be properly examined.

\section{III \\ Learning to Laugh?}

If laws specified in Book $\mathrm{V}$ are parodic, then their surface-level meanings are false: Socrates does not believe Kallipolis should be instantiated as it stands. Yet we cannot infer from this that it is meant to be wholly facetious. If we make this inference, then we fall back onto thinking in terms of extremes like

${ }^{24}$ Saxonhouse, 'Comedy in Callipolis', pp. 895-7.

${ }^{25}$ Cf. Fendt and Rozema, Platonic Errors, p. 65. Plato similarly problematizes Kallipolis in the outer frame by making it inconsistent with dramatic aspects of the Republic: Kallipolis undermines itself because the conversation that creates it could not arise in Kallipolis. For instance, Adeimantus and Glaucon could not philosophize in Kallipolis because they are below thirty years old (537d), and while most mimetic poetry is banned and is allowed only if it imitates decent characters, Socrates narrates the entire Republic and imitates many characters, including the indecent Thrasymachus. See Roochnik, Beautiful City, pp. 69-71; and Saxonhouse, 'The Socratic Narrative', pp. $740-1$. 
Glaucon. In other words, the parody is meant to put us to work as readers as well. So, if we recognize the hortatory purpose of the parody, then we must consider the reforms more deeply to see in what senses they might be parodic or ideal for Socrates and for Plato. We need not worry that an ironic reading opens the door for a commentator to invoke irony to explain any problematic passage. Rather, careful attention to context and textual language will bear out whether a passage is plausibly ironic, and although this sometimes means relying on details that are not always transparent, Plato requires only that we question the surface-level proposition as much as we do a friend who says that the weather is gorgeous when it is hailing.

One reason to believe that the situation is as complex as I have painted it is that there is an intimate relation between the laws of Book V and the Noble Lie (gennaion pseudos) at the end of Book III, and that Plato seems to think that elements of the Noble Lie are in some sense true. In light of this, I want to suggest what I hope is a potentially fruitful and interesting project. Perhaps this is the best entry point into spelling out the ironic interpretation I have raised. Similar to my view with respect to Republic V, Kateri Carmola has recently argued that the Noble Lie is an attempt to provoke Glaucon to work and to correct his unrealistic conception of justice. ${ }^{26}$ I suggest that we should investigate the interconnections between three relations: (i) that between the Noble Lie and the laws in Republic V; (ii) that between the Noble Lie and Glaucon; and (iii) that between Republic V and Glaucon. If Carmola and I are correct, then one line worth developing is that laws articulated in Republic $\mathrm{V}$ are a parody of Glaucon's extremism, which Socrates flags and tries to correct as early as the Noble Lie, and that Glaucon fails to think more critically on both occasions. While I hope that I have shown the merits of the ironic reading on which this interpretative project rests, much more work is necessary. To strengthen the argument, we should also attend to the wider use of makaria and $\bar{o}$ makarie in classical Athens and to Plato's treatment of Glaucon in the Symposium and the Phaedrus. We would also have to explain fully which features of Kallipolis are meant as a parody and how we are then to understand the analogy between parts of the city and parts of an individual's psyche. Further study of Aristotle's reception of the Republic and the politics of the Academy will also be instructive. If anyone knew Plato's authorial intentions, it was probably Aristotle, and if Aristotle sees Kallipolis as Plato's political ideal, then any ironic reading must defend itself against this fact.

To conclude, I should note that I have not fully answered an important question: why does Socrates use irony and parody in the first place to teach Glaucon how to think critically? Earlier, I gave part of the answer. If taken literally, these devices present absurdities that can shock us into seeing what is really the case or, if they include mockery, they can shame us into abandoning

${ }^{26}$ See Kateri Carmola, 'Noble Lying: Justice and Intergenerational Tension in Plato's Republic', Political Theory, 31.1 (2003), pp. 39-62. 
a false belief or altering a mode of thinking. Yet there is more to the story. Both irony and parody enable critical thinking. Like dialectic, both devices simultaneously offer two sides: irony and parody contrast what is meant with what is explicitly stated or shown. Certainly, both the said and unsaid poles say, 'Nice hair day, Pete!' and 'Your hair is dishevelled, unattractively so' can stand alone. Yet when we take each side independently, neither is ironic and the irony is lost. This is because irony, as well as parody, presents dual meanings. The meaning of each pole depends on its relation to the other pole and its relation to a holistic structure. Both poles must be present in order to have irony and parody because irony and parody consist in the relations between those poles. To get the joke, we must take both offers, see their limitations, and negotiate the relationship between them. The active negotiation between dual positions that both irony and parody presuppose and cultivate opposes the process that Glaucon uses by dealing in extremes. The same process and effect of irony and parody exist for the reader, in the outer frame. A reader of the Republic can locate and understand its ironic and parodic aspects only if she grapples with the text itself and what lies between the exchanges of its interlocutors. This is the independent criticism and intellectual activity that Socrates attempts to cultivate in Glaucon through his ironic use of makaria and parody. He exhorts Glaucon to think critically, to abandon his extremism and to navigate between surface-level and deeper meanings. What Socrates does for Glaucon, Plato does for us. ${ }^{27}$

Jonathan Fine

COLUMBIA UNIVERSITY

${ }^{27}$ I owe many thanks to Christina Tarnopolsky, Rick Benitez and Calvin Normore for their helpful comments on earlier drafts of this paper and for their enthusiastic encouragement. 